\title{
Perawatan Satu Kunjungan Restorasi Pasak Fiber Reinforced Composite Pada Gigi Insisivus Atas
}

\author{
Ria Ariani* dan Wignyo Hadriyanto** \\ *Program Studi Konservasi Gigi, PPDGS Fakultas Kedokteran Gigi Univeristas Gadjah Mada \\ **Bagian Konservasi Gigi Fakultas Kedokteran GigiUniversitas Gadjah Mada Yogyakarta \\ *JI Denta no 1 Sekip Utara, Yogyakarta, e-mail: riadikandra@yahoo.com
}

\begin{abstract}
ABSTRAK
Perawatan saluran akar satu kali kunjungan memberikan keuntungan antara lain memperkecil resiko kontaminasi mikroorganisme dan menghemat waktu perawatan. Pasak fiber reinforced composite memiliki ikatan yang baik dengan dentin menggunakan semen resin dan inti dari resin. Penggunaan pasak bisa mengurangi risiko fraktur. Tujuan penulisan laporan kasus ini adalah untuk mengevaluasi hasil restorasi gigi 11 nekrosis pulpa pasca perawatan saluran akar disertai restorasi dengan pasak fiber reinforced composite. Pasien wanita, 22 tahun datang ke Klinik Konservasi RSGM FKG UGM untuk merawat gigi depan atas kanan yang berlubang. Berdasarkan pemeriksaan subjektif, objektif dan radiografis diperoleh diagnosis gigi 11 nekrosis pulpa. pasca perawatan saluran akar gigi Gigi direstorasi dengan resin komposit dan pasak fiber reinforced composite. Kesimpula dari hasil evaluasi klinis saat kontrol tidak ada keluhan rasa sakit dan pasien merasa puas.

Maj Ked Gi. Juni 2013; 20(1): 45 - 51.
\end{abstract}

Kata kunci: perawatan saluran akar satu kunjungan, fiber reinforced composite, restorasi resin komposit, incisivus, nekrosis

\begin{abstract}
One Visit Treatment of Fiber Reinforced Compositerestoration in Maxillary Right First Incisivus. One visit root canal treatment is advantageous to minimize the risk of microorganism contamination. It saves time and more tolerable for the patients. Fiber reinforced composite post is fabricated, and it has been known to have a good bond with dentinal wall of root space, resin cement and composite resin core. The use of this post could decrease the risk of fracture. The purpose of this paper is to report the results of dental restoration 11 pulp necrosis after root canal treatment with resin composite restorations and post fiber reinforced composite. A 22 year-old female patient who came to Faculty of Dentistry UGM complained about her maxillary right incisor teeth which decayed and needed a treatment. Based on the subjective, objective and radiograph examinations, it was diagnosed that the pulp was necrotic. After one visit root canal treatment and based on clinical evaluation, it is concluded that the right upper incisor that was restored using fiber reinforced composite post and composite resin showed no pain, and patient was satisfied.

Maj Ked Gi. Juni 2013; 20(1): 45 - 51.
\end{abstract}

Keywords: one visit root canal treatment, fiber reinforced composite, composite resin restorations, incisivus, nekrosis

\section{PENDAHULUAN}

Karies gigi merupakan suatu penyakit jaringan keras gigi yang melibatkan email, dentin, dan pulpa. Kerusakan jaringan keras gigi bila dibiarkan tanpa perawatan dapat mengakibatkan kematian pulpa. Penyebaran infeksi yang berlanjut ke jaringan periapikal dapat menyebabkan rasa nyeri dan gigi menjadi nekrosis. Gigi yang mengalami nekrosis memerlukan perawatan saluran akar yang bertujuan untuk membersihkan ruang pulpa dari jaringan pulpa yang telah terinfeksi, kemudian membentuk saluran akar untuk persiapan obturasi. ${ }^{2}$ Berdasarkan jumlah kunjungan perawatan saluran akar ada dua macam jenis perawatan yaitu, perawatan lebih dari satu kunjungan (multi visit) dan satu kunjungan (one visit). Keuntungan perawatan satu kunjungan dapat memperkecil resiko kontaminasi mikroorganisme dalam saluran akar dan mempersingkat kunjungan. ${ }^{3}$

Gigi yang telah dirawat saluran akar seringkali hanya memiliki sedikit sisa jaringan keras gigi. Semakin sedikit jaringan keras gigi yang tersisa semakin berkurang kekuatan gigi untuk menahan tekanan kunyah sehingga gigi pasca perawatan saluran akar menjadi getas dan beresiko terjadinya fraktur, kerena kelembaban telah berkurang. ${ }^{4}$ Gigi pasca perawatan saluran akar lebih sering terjadi 
fraktur vertikal karena faktor trauma. Gigi pasca perawatan saluran akar yang banyak kehilangan struktur gigi memerlukan restorasi dengan pasak sehingga dapat berfungsi normal. ${ }^{5}$

Pasak merupakan suatu bangunan logam atau non logam yang dimasukkan ke dalam saluran akar untuk meningkatkan retensi mahkota dan meneruskan tekanan yang diterima gigi secara merata ke sepanjang akar. Berdasarkan pembuatannya dibedakan menjadi dua, yaitu fabricated dan prefabricated. Berdasarkan bahan pembuatannya dibagi dua, yaitu logam dan non logam. Beberapa pasak non logam yaitu pasak resin komposit, keramik dan fiber reinforced polymers. ${ }^{5}$ Fiber reinforced polymer terbuat dari karbon atau serat silica yang diselubungi oleh polimer resin, biasanya epoxy resin disebut fiber reinforced composite (FRC). Pasak FRC terdiri atas kumpulan serat yang berdiameter 7-10 $\mu \mathrm{m}$ dan memiliki bentuk jallinan pita, anyaman dan longitudinal. ${ }^{4}$

Pasak FRC menjadi pilihan karena memiliki modulus elasisitas menyerupai dentin sehingga tekanan dapat didistribusikan sepanjang pasak dan diseluruh akar. ${ }^{6}$ Pasak FRC dibuat sendiri oleh operator dengan anyaman pita fiber berupa polietilen fiber dan komposit flowable dimasukkan ke dalam saluran pasak. Pasak FRC fabricated dapat menyesuaikan dengan bentuk saluran pasak. ${ }^{4}$ Pasak
FRC tidak memerlukan pelebaran saluran akar yang berlebih, hal ini dapat mengurangi resiko fraktur akar maupun perforasi akar. ${ }^{7}$ Pemilihan restorasi akhir tergantung dari besar struktur gigi yang tersisa, tekanan horizontal dan beban pengunyahan. ${ }^{7}$ Pada gigi anterior dengan tepi marginal yang utuh dapat dilakukan restorasi dengan menggunakan resin komposit. Artikel ini bertujuan untuk memaparkan perawatan satu kunjungan restorasi pasak fiber reinforced composite pada gigi insisivus atas.

\section{STUDI KASUS}

Pasien wanita usia 22 tahun datang ke Klinik Konservasi RSCM FKC UGM, dengan keluhan ingin menambal gigi depan atas yang sakit seminggu yang lalu. Gigi tersebut pernah ditambal satu tahun yang lalu dan tambalan lepas dua bulan yang lalu dan tidak ditambal lagi. Pemeriksaan objektif gigi 11 terdapat kavitas pada bagian mesial dengan kedalaman mencapai pulpa. Pemeriksaan perkusi, palpasi dan mobilitas menunjukkan respon negatif. Tes vitalitas juga menunjukkan respon negatif. Pemeriksaaan radiografis terdapat gambaran karies mencapai pulpa dan tidak terdapat kelainan periapikal (Gambar 1). Diagnosis: gigi 11 mengalami nekrosis pulpa. Perawatan yang dilakukan adalah perawatan saluran akar satu kunjungan dilanjutkan dengan restorasi resin komposit dengan pasak FRC.
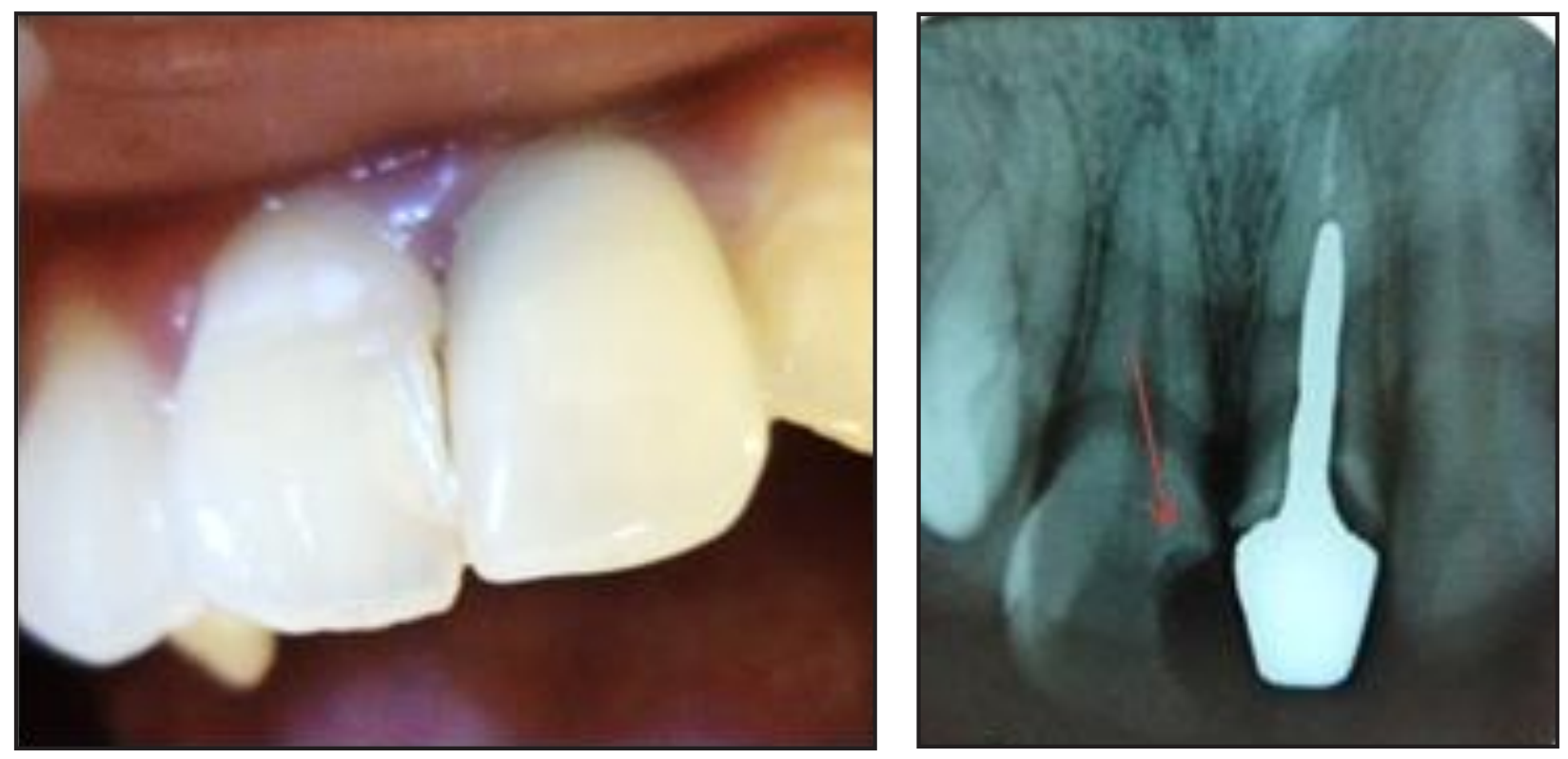

Gambar 1. Foto intraoral dan foto radiograf awal, karies dengan kedalaman mencapai pulpa 




(A)

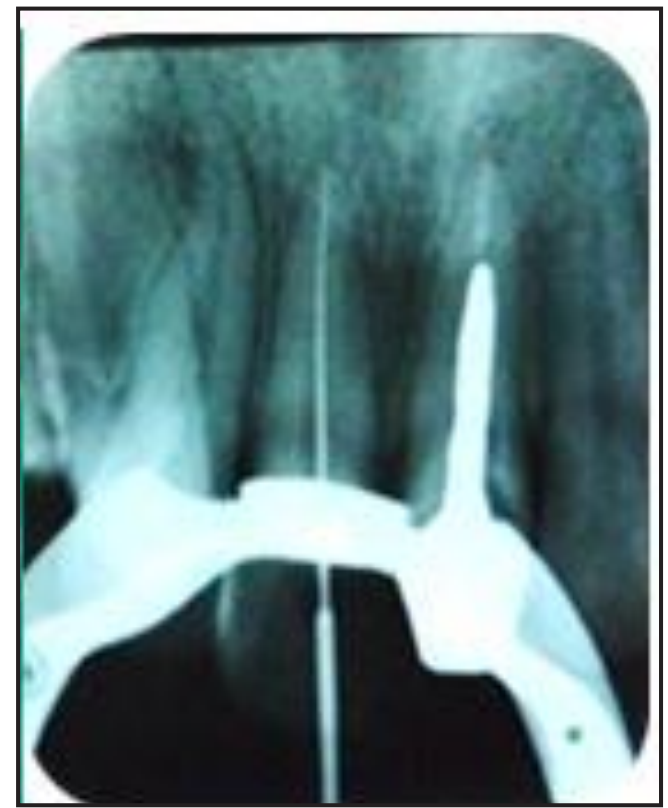

(B)

Gambar 2. Preparasi saluran akar (a) IAF; (b) radiograf pengukuran panjang kerja

Pada kunjungan I (7-1-2013) pasien dilakukan pemeriksaan subjektif, objektif, foto intraoral, diagnosis, penentuan rencana perawatan. Berdasarkan pemeriksaan tersebut maka diagnosis gigi 11 adalah nekrosis pulpa. Pasien diberi penjelasan mengenai prosedur rencana perawatan dan biaya serta waktu perawatan, jika pasien setuju dengan tindakan perawatan ini maka pasien menandatangani informed concent.

Perawatan saluran akar dimulai dengan pembukaan akses kavitas dengan menggunakan endo access bur dan pembukaan atap pulpa dengan bur diamendo (Dentsply) sampai akses masuk ke orifis terbuka (Gambar 1 dan 2). Pemasangan isolator karet (ruber dam) pada daerah kerja. Saluran akar dilakukan irigasi dengan $\mathrm{NaOCl} 2,5 \%$ dan dikeringkan dengan paper point steril. Dilakukan pengukuran panjang kerja estimasi berdasarkan foto radiograf dan pengukuran panjang kerja dengan menggunakan apex locator (Propex II Dentsply). Dilanjutkan dengan preparasi biomekanik dengan teknik stepback menggunakan $k$-file. Tahap pertama adalah preparasi pada daerah $1 / 3$ apikal, $K$-file awal (IAF) yang dapat masuk sepanjang kerja adalah $K$-file \#25 dimasukkan dalam saluran akar dengan
PK 23mm. Preparasi dilanjutkan dengan no 30 sampai 40 Master Apical File (MAF) dengan PK 23 $\mathrm{mm}$, rekapitulasi dengan file dibawahnya dengan $\mathrm{PK}$ yang sama.

Tahap kedua adalah preparasi badan saluran akar. File yang dipakai adalah sampai 3 nomer yang lebih besar dari MAF dengan panjang kerja dikurangi $1 \mathrm{~mm}$ setiap kenaikan satu nomer file. Setiap pergantian alat dilakukan rekapitulasi dengan file MAF dengan PK $23 \mathrm{~mm}$. dilakukan coronal flaring dengan menggunakan hedstroem file no 60 PK $19 \mathrm{~mm}$ dan finishing dengan menggunakan file no 40 PK $23 \mathrm{~mm}$ dengan gerakan circumferential filling. Setiap pergantian file dilakukan irigasi dengan $\mathrm{NaOCl} 2,5 \%$.

Setelah perawatan biomekanik selesai dilakukan pengepasan gutta perca sesuai MAF \#40 dengan PK $23 \mathrm{~mm}$ dan dikonfirmasi dengan radiograf. Gutta perca disterilkan dalam larutan $\mathrm{NaOCl} 2,5 \%$ selama 1 menit dan dibilas alkohol 70\% kemudian dikeringkan. Pengisian saluran akar dengan teknik kondensasi lateral dan siler berbahan resin (Topseal, Denstply). Siler dimasukan dalam saluran akar dengan bantuan lentulo, gutta perca utama diolesi 


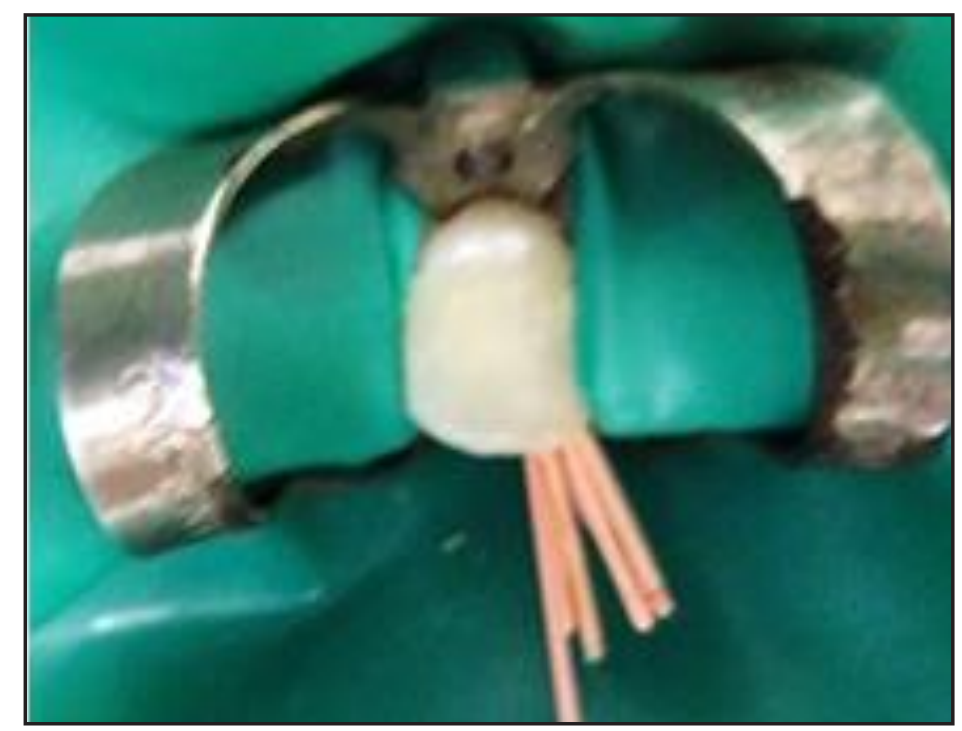

(A)

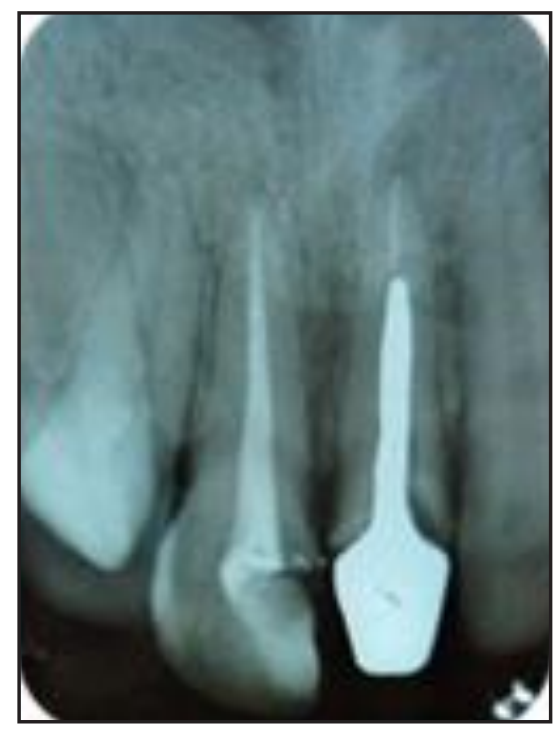

(B)

Gambar 3. (A) Gambaran klinis obturasi; (B) Radiograf obturasi

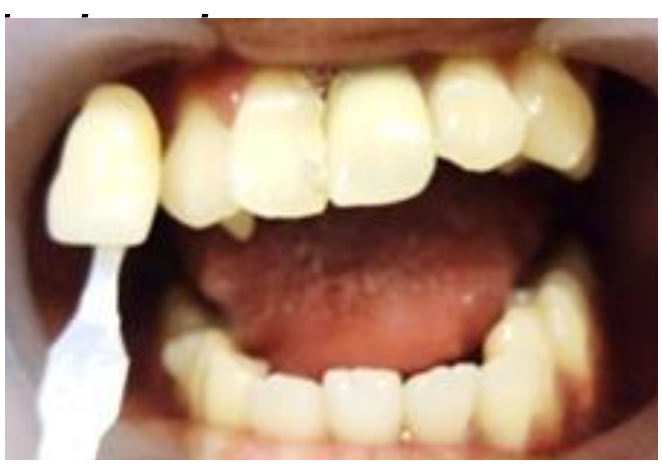

(A)

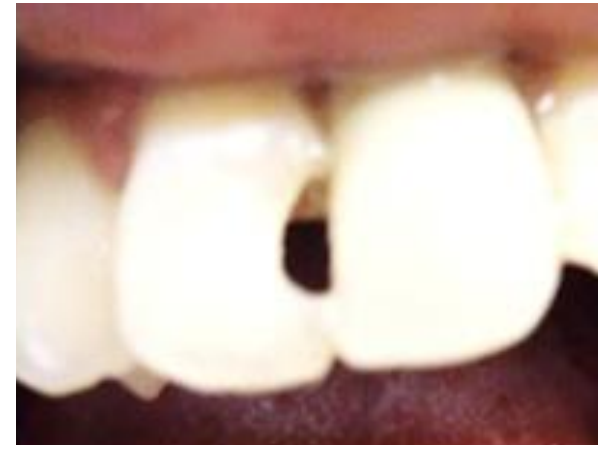

(B)

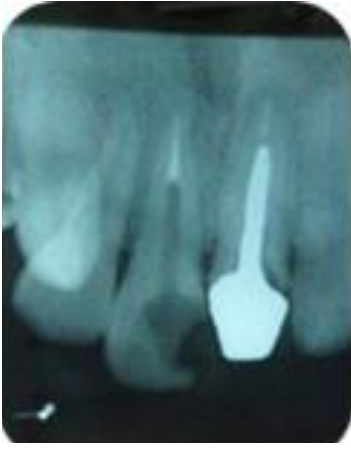

(C)

Gambar 4. (A) Pemilihan warna; (B) Gambaran klinis setelah preparasi; (C) Setelah preparasi saluran pasak

siler pada ujungnya lalu dimasukan dalam saluran akar (Gambar 3A dan 3B). Spreader dimasukan diantara gutta perca dan dinding saluran akar kemudian dimasukkan gutta perca tambahan sampai saluran terisi penuh. Gutta perca dipotong sampai batas orifis menggunakan plugger yang dipanaskan dan gutta perca dipadatkan. Diberi lining semenseng fosfat dan ditumpat sementara (orafil G). Dilakukan pengambilan radiograf untuk melihat hasil obturasi. Radiograf menunjukkan hasil obturasi yang hermetis.

$$
\text { Pada kunjungan II (17-1-2013) kontrol }
$$

1 minggu setelah perawatan saluran akar.
Dilakukan pemeriksaan subjektif, objektif. Hasil pemeriksaan subjektif, tidak ada keluhan sakit. Hasil pemeriksaan objektif, tumpatan sementara masih dalam keadaan baik, perkusi dan palpasi negatif. Dilakukan penentuan warna gigi menggunakan Vita lumin shade guide, didapatkan warna A2 (Gambar 4). Setelah dilakukan pembongkaran tumpatan sementara, dilakukan preparasi kavitas, semua cavosurfacemargin yang tidak didukung dentin dibevel dengan desain chamfer-shoulder (hollowground bevel) menggunakan bur intan bentuk flame. Dilanjutkan dengan preparasi saluran 


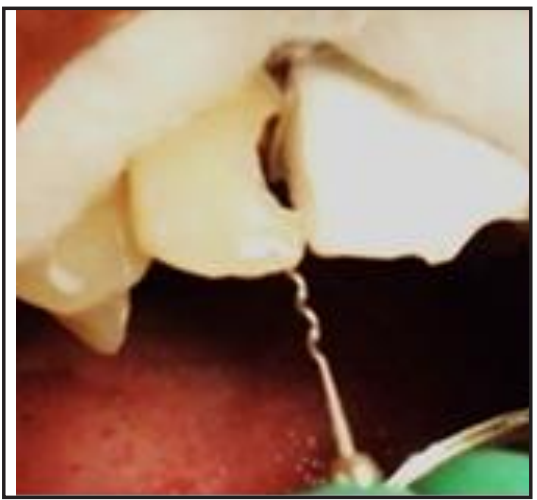

(A)

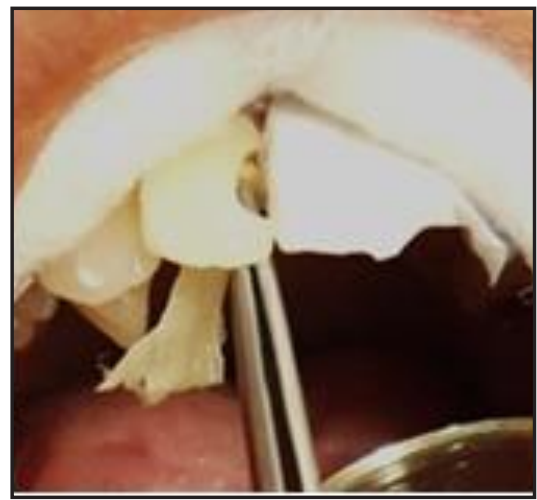

(B)

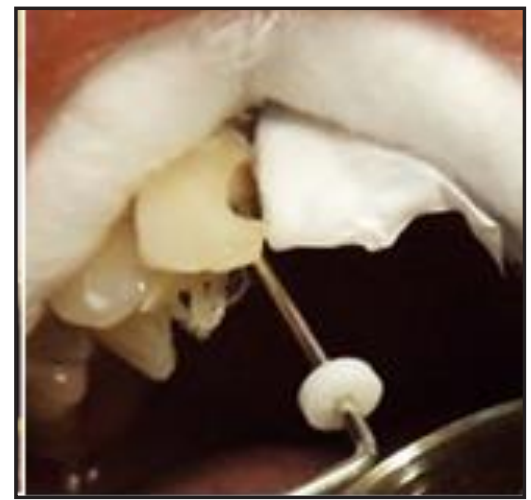

(C)

Gambar 5. (A) Aplikasi semen resin; (B) Insersi pasak fiber reinforced composite; (C) Pita fiber dikondensasi dengan plugger

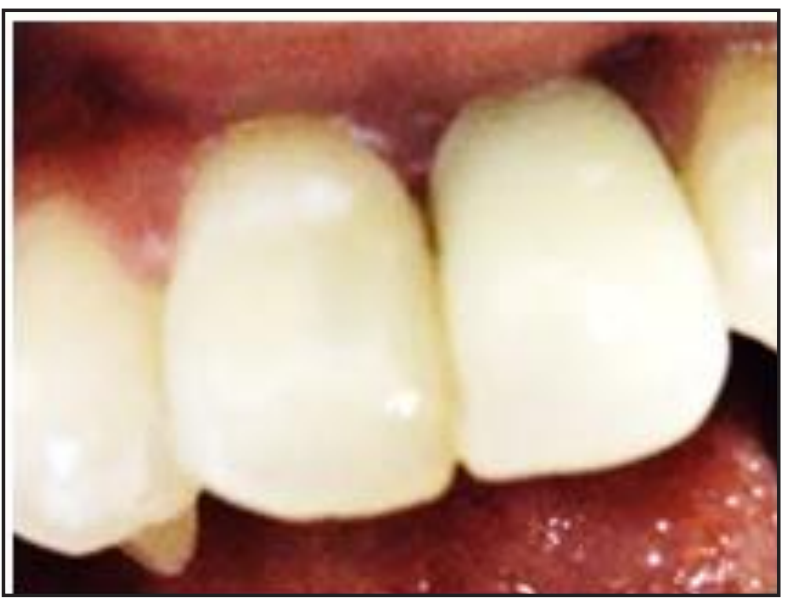

(A)

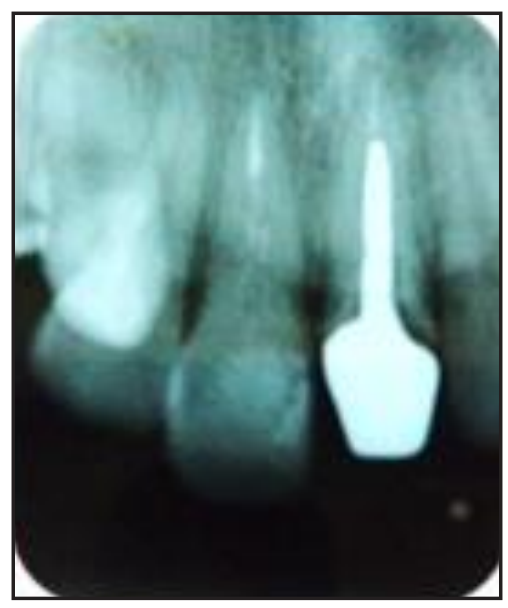

(B)

Gambar 6. (A) Gigi 11 pasca restorasi tampak Labial; (B) Gambaran radiografis

pasak diawali dengan pembuangan gutta perca dengan memasukkan plugger yang dipanaskan ke dalam saluran pasak kemudian dilanjutkan dengan peeso reamer dari ukuran no 1 sampai 3 dengan panjang kerja $18 \mathrm{~mm}$ sehingga menyisakan gutta perca $5 \mathrm{~mm}$. Dilakukan irigasi pada saluran pasak dengan larutan akuades dan dikeringkan dengan paper point.

Dilanjutkan dengan pemasangan pasak dengan pasak fiber customized Construct (Kerr). Serabut pita fiber dipotong sepanjang $30 \mathrm{~mm}$ kemudian diaplikasikan resin (Construct Kerr) diatas permukaan serabut fiber. Pemberian etsa ke seluruh permukaan gigi dan saluran pasak selama 15 detik dan dibilas dengan air. Saluran pasak dikeringkan dan dilanjutkan dengan aplikasi bonding diaktivasi sinar 20 detik. Aplikasi semen resin (Build-it FR) kedalam saluran pasak menggunakan lentulo. Serabut fiber dimasukkan kedalam saluran pasak menggunakan pinset kemudian dikondensasikan menggunakan plugger, kemudian diaktivasi sinar selama 20 detik (Gambar 5).

Penumpatan bahan resin komposit warna A2 (Herculite precis, Kerr) dibentuk dengan dengan memakai seluloid strip dan plastis instrument. Penumpatan bahan resin komposit pada permukaan 
kavitas dilakukan secara incremental, kemudian diaktivasi sinar selama 20 detik. Prosedur ini dilakukan sampai seluruh permukaan kavitas terisi penuh dengan bahan resin komposit. Finishing restorasi resin komposit menggunakan extra fine finishing bur, kemudian dipoles menggunakan polishing disc (optidisc, Kerr Hawe) dan polishing brush (opti shine, Kerr Hawe), dan bagian proksimal menggunakan grinding strip. Pasien diinstruksikan datang 1 minggu kemudian untuk kontrol.

Kunjungan ke III, (28-1-2013). Kontrol satu minggu pasca restorasi resin komposit. Dilakukan pemeriksaan subjektif, objektif. Hasil pemeriksaan subjektif, tidak ada keluhan sakit. Hasil pemeriksaan objektif, tumpatan dalam keadaan baik, perkusi dan palpasi negatif, gingival normal, tidak terdapat perubahan warna tumpatan, hubugan tepi baik. Pada gambaran radiograf pada gambar 6 terlihat pasak fiber reinforce composite dan restorasi resin komposit terlihat baik, tidak ada lesi periapikal.

\section{PEMBAHASAN}

Perawatan saluran akar satu kali kunjungan cukup menguntungkan diantaranya dapat menghemat waktu kunjungan dan meminimalisir kontaminasi bakteri, tidak diperlukan pengantian medikasi intrakanal dan tumpatan sementara. ${ }^{2,8}$ Indikasi perawatan saluran akar satu kali kunjungan pada kasus sebagai berikut: trauma iatrogenic tanpa lesi periapikal, pulpitis ireversibel tanpa lesi periapikal, gigi nekrosis pulpa tanpa gejala klinik dan lesi periapikal. tidak ada eksudat dalam saluran akar. kontra indikasi untuk perawatan saluran akar satu kunjungan untuk kasus sebagai berikut: adanya lesi periapikal, adanyakelainan anatomis, periodontitis akut. ${ }^{9}$

Pemakaian bahan irigasi pada perawatan saluran akar satu kali kunjungan adalah sodium hipoklorit $2,5 \%$ dikombinasikan dengan chlorhexidine gluconate $2 \%$. Pada perawatan saluran akar satu kunjungan penggunaan chlorhexidine gluconate $2 \%$ s angat bermanfaat karena memiliki sifat antimikroba terhadap enterococcus faecalis yang dapat menyebabkan kegagalan perawatan. ${ }^{10,11}$ Sodium hipoklorit $2,5 \%$ merupakan bahan yang bersifat antimikroba, efektif untuk melarutkan jaringan pulpa, pemutih dan antiseptik yang kuat. Konsentrasi sodium hipoklorit 2,5\% efektif membunuh bakteri streptococcus mutans, prophyromonas gingivalis, namun sodium hipoklorit tidak mempunyai sifat antimikroba terhadap enterococcus faecalis. ${ }^{13}$ Penggunaan kedua bahan irigasi ini lebih baik jika digunakan secara kombinasi dalam perawatan saluran akar. Keberhasilan perawatan saluran akar satu kunjungan tergantung dari seleksi kasus yang tepat, keterampilan operator serta ketaatan terhadap standar prinsip endodontik. ${ }^{11}$

Gigi pasca perawatan saluran akar menjadi lemah dalam menerima tekanan mastikasi. Pada gigi anterior yang tidak banyak mengalami kehilangan banyak struktur gigi untuk restorasi akhirnya dapat direstorasi resin komposit dijadikan sebagai restorasi akhir. Penggunaan pita FRC dapat digunakan untuk membantu retensi mekanis. ${ }^{2}$ Penggunaan pasak pada gigi pasca perawatan saluran akar dipertimbangkan berdasarkan besarnya struktur gigi yang tersisa dan sebagai pendukung restorasi akhir. ${ }^{4}$

Penggunaan pasak FRC pada kasus ini, karena gigi insisivus sentral ini tidak memerlukan perbaikan inklinasi dan masih memiliki jaringan keras gigi yang masih banyak. Keuntungan dari pemilihan pasak ini adalah menghilangkan struktur jaringan gigi yang minimal, dapat diinsersikan pada saluran pasak yang flared, saluran akar yang tipis dan saluran akar yang membengkok serta dapat membentuk ikatan yang baik dengan kompleks dentin akar. ${ }^{13}$ Pada restorasi yang memerlukan estetis bila menggunakan pasak karbon fiber atau logam dapat mempengaruhi warna akhir restorasi. Untuk mengatasinya dengan menggunakan pasak fiber resin komposit prefabricated atau fabricated. ${ }^{5}$

Fiber Reinforced Composite (FRC) adalah suatu bahan komposit yang mengandung fiber, untuk meningkatkan sifat-sifat fisik dari komposit. FRC merupakan material dengan kekuatan mekanikal tinggi, dan memiliki modulus elastisitas hampir sama dengan dentin sehingga dapat mengurangi terjadinya fraktur. Sifat yang dimiliki pasak FRC ini dapat memperkuat akar sehingga tekanan dapat didistribusikan merata sehingga menghindari fraktur akar. Pasak dapat berikatan dengan dentin saluran 
pasak dengan baik karena mekanisme adhesif yang menggunakan resin semen. Teknik direk adalah prosedur restorasi dimana preparasi dan aplikasi bahan dilakukan dalam satu kali kunjungan. ${ }^{7}$

Pada kasus ini menggunakan sementasi pasak menggunakan semen resin. Prosedur sementasi merupakan faktor kritis dengan adanya kegagalan yang terjadi antara ikatan semen dengan pasak. Untuk itu diperlukan semen yang mampu berikatan baik dengan dentin saluran pasak. Semen resin menghasilkan retensi yang baik, sehingga dapat menciptakan ikatan monoblok yang tidak terpisahkan antara dinding saluran pasak dengan pasak FRC. Selain itu semen resin dapat menurunkan resiko terjadinya kebocoran serta memiliki ketahanan terhadap fraktur. ${ }^{14}$ Pemilihan resin komposit sebagai restorasi akhir pada kasus ini karena jaringan keras gigi yang tersisa masih banyak. Pada waktu evaluasi menunjukkan keadaan gigi 11 setelah PSA dalam keadaan bai, tidak terdapat lesi periapikal dan secara klinis dapat digunakan dengan baik serta tidak terdapat keluhan dari pasien. Pasien merasa puas dengan hasil perawatan.

Dapat disimpulkan berdasarkan pembahasan diatas bahwa perawatan satu kali kunjungan mamberikan keuntungan dibandingkan dengan perawatan beberapa kali kunjungan. Pemilihan restorasi akhirberupa restorasi komposit direct karena masih memiliki tepi marginal yang utuh sehinggapenggunaan restorasi direct dengan sistem adhesif ini dapat digunakan sebagai restorasi gigi anterior pasca perawatan saluran akar. Pasak FRC dapat dipilih sebagai alternatif perawatan pada gigi anterior pasca perawatan saluran akar.

\section{DAFTAR PUSTAKA}

1. Tarigan R. Perawatan pulpa gigi. Jakarta: Penerbit Widya Medika; 1994. H. 181-194.

2. Ingle JI, Backland LK . Endodontics. Ed 5. London: BC Decker Inc; 2002. H. 203-10.
3. Grossman LI, Oliet S, Del Rio C. E. Ilmu endodontik dalam praktek (terj). Ed 11. Jakata: Penerbit Buku Kedokteran EGC; 1995. H. 196-380.

4. Newman MP, Yaman P, Dennison J, Rafter M, Billy E. Fracture restored with composite. J ProsthDent. 2003; 89: 360-367.

5. Cheung W. A review of management of endodontically treated teeth. J Am Dent Assoc. 2005; 611-619

6. Freilich MA, Meirs JC, Duncan JP, Goldberg AJ. Fiber reinforced composites in clinical dentistry, Quintessence Publishing; 2000. H. 9-21.

7. Nam SH, Chang HS, Min KS, Lee Y, Cho HW, Bae $J M$. Effect of the number of residual walls on fracture resistances, failure patterns, and photoelasticity of smulated premolar restored with or without fiber reinforced composites posts. J Endod. 2010; 36: 297-301.

8. Akkayan B, Gulmez T. Resistance to fracture of endodontically treated teeth restored with different post post. Systems. J Prosth Dent. 2002; 87: 431-437.

9. Eccles JD, Green RM. Konservasi gigi (terj). Ed 2. Jakarta: Penerbit Universitas Indonesia; 1994. H. $145-150$

10. Nisaan J, Dimitry Y, Assif D. The use reinforced composite resin cement as compensation for reduced post length. J Prosthet Dent. 2001; 86: 304-308.

12. Gutmann JL, Dumsha TC, Lovdahl PE. Problem solving in endodontics. St Louis: Mosby Co; 2006.

13. Haselton DB. Color atlas of endodontics. Restoration of the endodontically treated tooth. St Louis : Mosby Co; 2005.

11. Rustin SA, Endang R. Perawatan saluran akar satu kali kunjungan pada gigi premolar kedua kiri mandibula dengan nekrosis pulpa disertai lesi periapikal. Maj Ked Gigi. 2007; 14 (1): 23-28.

14. Anna M, Johanna T. Bonding of composite resin luting cement to fiber reinforced composite root canal posts. J Adhes Dent. 2004; 6: 319-25. 